\title{
Suicide among Physicians and Methodological Similarities of MEDLINE/PubMED and BVS/BIREME Open Access Bibliographic Databases: A Systematic Review with Metanalysis
}

\author{
Kécia Silva Damasceno1,2, Élcio de Sousa Barbosa3 ${ }^{3}$ João Vitor Cândido Pimentel², \\ Antonio Gilvan Teixeira Júnior², Airton César Pinheiro de Meneses², Jucier Gonçalves Júnior², \\ Danilo Ferreira de Sousa4, Paulo Sérgio da Costa Lima5, Iara Bezerra Sales', \\ Antonio Souto Gouveia', Elisabethe Peres Biruel6, Modesto Leite Rolim Neto', \\ Vânia Barbosa do Nascimento ${ }^{1}$
}

\footnotetext{
${ }^{1}$ Health Sciences Posgraduation Program, Faculdade de Medicina do ABC-FMABC, Santo André, SP, Brazil

${ }^{2}$ Medicine Course, School of Medicine, Universidade Federal do Cariri-UFCA, Barbalha, CE, Brazil

${ }^{3}$ Library Science Degree Course, Universidade Federal do Cariri-UFCA, Juazeiro do Norte, CE, Brazil

${ }^{4}$ Nursing Course, Faculdade de Juazeiro do Norte-FJN, Juazeiro do Norte, CE, Brazil

${ }^{5}$ Information Systems Course, Faculdade de Juazeiro do Norte-FJN, Juazeiro do Norte, CE, Brazil

${ }^{6}$ Latin American and Caribbean Center on Health Sciences Information-BIREME, São Paulo, SP, Brazil

Email: modestorolim@yahoo.com.br
}

How to cite this paper: Damasceno, K.S., de Sousa Barbosa, É., Pimentel, J.V.C., Teixeira Júnior, A.G., de Meneses, A.C.P., Gonçalves Júnior, J., de Sousa, D.F., da Costa Lima, P.S., Sales, I.B., Gouveia, A.S., Biruel, E.P., Neto, M.L.R. and do Nascimento, V.B. (2017) Suicide among Physicians and Methodological Similarities of MEDLINE/ PubMED and BVS/BIREME Open Access Bibliographic Databases: A Systematic Review with Metanalysis. Health, 9, 352-375. https://doi.org/10.4236/health.2017.92025

Received: November 22, 2016 Accepted: February 20, 2017 Published: February 23, 2017

\begin{abstract}
Background: Suicide among physicians is a serious public health issue, with an extremely complex and multifactorial behavior. Aim: The aim of this study was to use the theme "Suicide among Physicians" to exemplify the analysis of methodological similarities between the scientific content available at MEDLINE and BVS databases, as scientific research tools. Methods: This is a systematic review with metanalysis. The following combinations of keywords were used for data search in the referred databases: "suicide" AND "physicians" AND "public heath". Results: Three hundred and thirteen publications were identified, but only 16 studies were chosen. Great association was found between MEDLINE and BVS databases and the Odds Ratio regarding the theme: "Suicide among physicians". Conclusions: Considering the similarities found in the utilization of the two analyzed databases, it was possible to identify that suicide among physicians is associated with the exercise of an important professional role in the society and in the workplace. With regard to scientific information, the p-value-obtained value $(<0.05)$ seems to be sta-
\end{abstract}


Copyright $(0) 2017$ by authors and Scientific Research Publishing Inc. This work is licensed under the Creative Commons Attribution International License (CC BY 4.0).

http://creativecommons.org/licenses/by/4.0/

\section{Open Access}

tistically significant for the association between the suggested theme and the methodological similarities of the scientific information available in the analyzed databases. Thus, these open-access research tools are considered scientific reliable tools.

\section{Keywords}

Suicide, Physicians, Public Health, Databases, Scientific

Communication and Disclosure

\section{Introduction}

Around 1 million deaths by suicide are registered every year-17\% of them are related to Indians and $14 \%$ happen in developed countries [1] [2] [3].

However, the rate of suicide is not homogenous in all countries [4] [5]. Physicians usually commit suicide in higher frequency compared to the general population [6] [7] [8]. Thus, the decrease of suicide mortality among physicians should be the main purpose of this working class to change this situation [8]. Hence, these professionals have 2.5 times higher chances of committing suicide than the active population [5] [9]. Since suicidal ideation is another risk factor for suicide, prevention actions aiming to avoid these thoughts and suicide itself have great importance not only for these physicians, but also for the entire workgroup [8] [10] [11] [12].

Furthermore, mental health studies including Medicine students point out high levels of depression, anxiety, and Burnout Syndrome. Nevertheless, these studies about suicide and mental health risk factors among active male physicians are rare [13] [14] [15]. Additionally, expressive levels of psychic suffering were found among physicians who committed suicide [15] [16] [17].

Therefore, more pieces of information about suicide among health professionals are necessary in most of the known sources. Such information could be used to monitor the risk of suicide, to define the concomitant risk factors for self-mutilation in medical population, or to help analyze mental health factors that contribute to physicians' suicide [15] [18].

Thus, we aim at exemplifying the research of such theme, "Suicide among Physicians," and its correlation with the available scientific content regarding Health Sciences in the main electronic bibliographic databases of open access to the full text content. This is done through the Brazilian Department of Health, which is named Biblioteca Virtual em Saúde-BVS/BIREME, in Brazil, and the US National Library of Medicine, also known as MEDLINE/PubMed, in the USA.

Therefore, this investigation presents the methodological development similarities of BVS/BIREME and MEDLINE/PubMed databases, as well as their reported controlled vocabulary: Descritores em Ciências da Saúde (DeCS) and Medical Subject Headings (MeSH). 


\section{Methods}

This is a systematic review with metanalysis following Cochrane Handbook [39] and Meta-Analyzes (PRISMA) [40] guidelines recommendations for conduction of both the systematic review and the metanalysis (Figure 1). Previously chosen inclusion/exclusion criteria were adopted to select the sample in the MEDLINE/ PubMed and BVS/BIREME databases, since they are the object of this study.

The search was conducted from January 1, 1996 to August 26, 2016 by means of the keywords found in DeCS/MeSH: "suicide", "physicians" and "public health". Data screening applied combinations and gray literature, as follows: \#1. "Suicide" [MeSH Terms], "Suicídio" (DeCS); \#2. "Physicians" [MeSH Terms], "Médicos" (DeCS); \#3. "Public heath” [MeSH Terms], "Saúde Pública” (DeCS), using the following research strategy: \#1 AND \#2 AND \#3. The formulation of

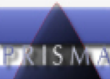

PRISMA 2009 Flow diagram
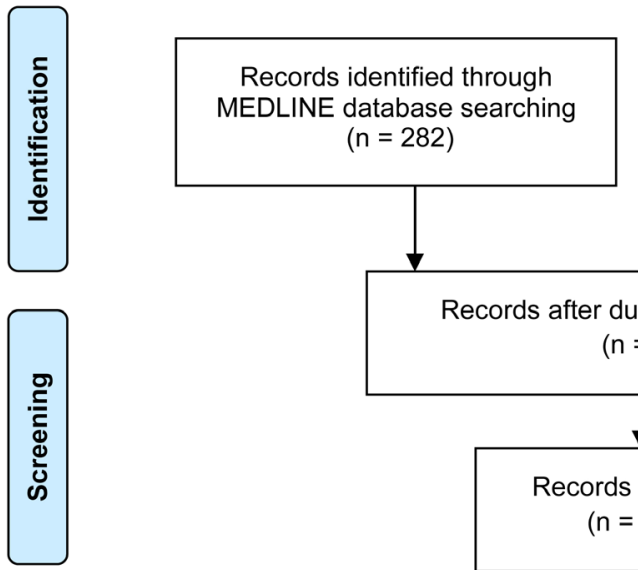

Additional records identified through BVS database $(n=282)$
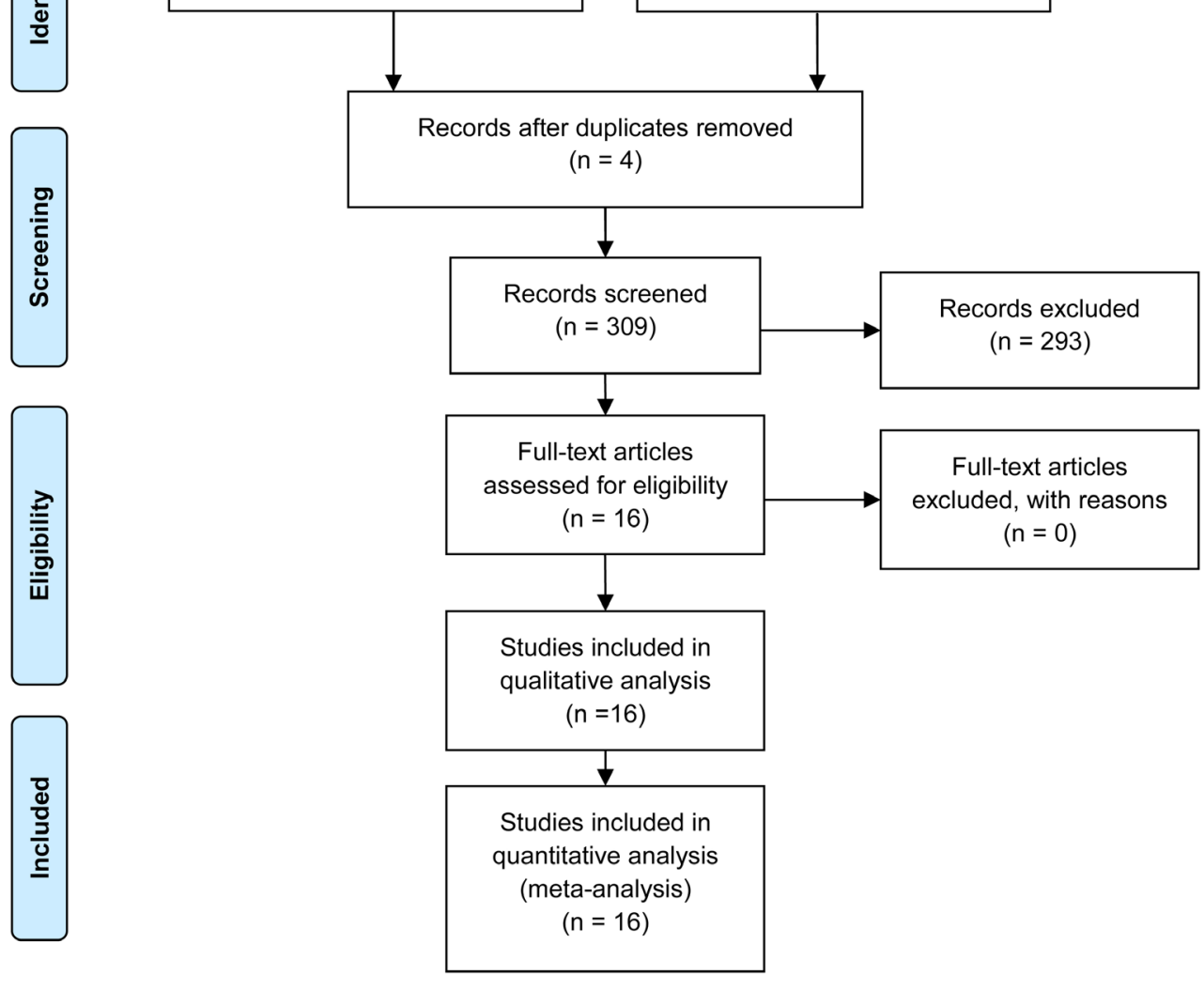

Figure 1. Flow diagram summarizes the process of study inclusion in this review. From: Moher, D., Liberati, A., Tetzlaff, J., Altman, D.G., The PRISMA Group (2009). Preferred Reporting Items for Systematic Reviews and Meta-Analyses: The PRISMA Statement. PLoS Med, 6(7): e1000097. doi:10.1371/journal.pmed1000097. Source: Developed by the authors (2016). 
the research question was structured based on the PICO acronym. Each word of the PICO component means: P: MEDLINE and BVS scientific databases; I: categorization of the selection of source-data and hierarchical system available in each analyzed database; $\mathrm{C}$ : collection of the available scientific information from January 1, 1996 to August 26, 2016; O: guarantee of reliable collected information to support the decisions taken by the investigators and Health Sciences professionals, which enabled the detailed description of the creation of the eligible criteria adopted herein.

The research question consists in: "Have the main open access bibliographic databases, MEDLINE/PubMed in the United States, and BVS/BIREME in Brazil, presented methodological similarities in the indexed scientific content during the last 20 years as a way to ensure reliability of the recovered information?" The theme "Suicide among Physicians" was used to illustrate such methodological similarities. The following types of studies were included: Classical Article, Clinical Study, Clinical Trial, Clinical Trial, Phase I, Clinical Trial, Phase II, Clinical Trial, Phase III, Clinical Trial, Phase IV, Controlled Clinical Trial, Corrected and Republished Article, Journal Article, Meta-Analysis, Multicenter Study, Observational Study, Overall, Randomized Controlled Trial, whose main theme was "Suicide among Physicians", in English, Spanish and Portuguese languages. Such time period was chosen due to the creation date of the PubMed health sciences scientific research portal in January of 1996. Exclusion criteria were comprised of articles that did not directly approach the theme 'Suicide among Physicians' or situations that resulted in such action, as well as of studies that did not have the open access availability to full text. Studies were chosen through electronic search in MEDLINE/PubMed and BVS/BIREME databases, in addition to gray literature. The R 3.3.1 statistical program was used for the statistical analysis.

Throughout the process of study selection, two reviewers worked independently and analyzed the studies to be included. When occurred disagreement between them, a third reviewer was used to make the final assessment on the inclusion or non-inclusion of the study. The entire content of chosen studies was analyzed.

\section{Results}

Based on research strategy, 282 publications were identified at MEDLINE and 31 at BVS, resulting in 313 publications; however, after undergoing the criteria and analyses of eligibility, 16 studies remained (Table 1). The repeated articles were computed only once in the final counting.

Based on the joined analysis of all articles submitted to the test, a combined Odds Ratio value of 1.85 CI (1.83 - 1.87) was found. It shows the association of MEDLINE database with BVS database and the Odds Ratio regarding the suicide theme among medical professionals. The obtained p-value $(<0.05)$ was statistically significant for the analyzed datum. The joined analysis of the included studies was made (Figure 2). Interpreting the figure below, each group of studies is represented with a line. 
Table 1. Suicide among physicians in the MEDLINE/PubMed and BVS/BIREME databases: main findings and limitations.

\begin{tabular}{|c|c|c|c|c|c|c|}
\hline $\begin{array}{c}\text { Authors and } \\
\text { year }\end{array}$ & Title & Sample & Objective & Main findings & Databases & Limitations \\
\hline $\begin{array}{c}\text { Palhares-Alves } \\
\text { HN et al., } \\
2015 \text { [5] }\end{array}$ & $\begin{array}{l}\text { Suicide among } \\
\text { physicians in } \\
\text { the state of São } \\
\text { Paulo, Brazil, } \\
\text { across one } \\
\text { decade }\end{array}$ & $\begin{array}{l}2297 \text { death } \\
\text { certificates, among } \\
\text { which suicide } \\
\text { represented } 50 \\
\text { cases, i.e. } 1.7 \% \text { of all } \\
\text { death causes. }\end{array}$ & $\begin{array}{l}\text { The purpose of } \\
\text { this study was } \\
\text { to describe the } \\
\text { mortality of } \\
\text { suicide among } \\
\text { physicians in } \\
\text { the state of São } \\
\text { Paulo, Brazil, } \\
\text { between } 2000 \\
\text { and } 2009 \text {. }\end{array}$ & $\begin{array}{l}\text { Deaths by } \\
\text { suicide usually } \\
\text { happen, on } \\
\text { average, } 20 \\
\text { years before } \\
\text { deaths by other } \\
\text { causes. There } \\
\text { was a significant } \\
\text { association } \\
\text { between being } \\
\text { single and/or } \\
\text { divorced with } \\
\text { suicide. Also, the } \\
\text { average mortality } \\
\text { rate during the } \\
\text { study period } \\
\text { was of } 4.2 \\
\text { deaths per } \\
100,000 \\
\text { physicians } \\
\text { registered in } \\
\text { the Regional } \\
\text { Medicine Council } \\
\text { from the State of } \\
\text { São Paulo. }\end{array}$ & $\begin{array}{l}\text { MEDLINE/ } \\
\text { PubMed }\end{array}$ & $\begin{array}{l}\text { In Brazil, the } \\
\text { possible loss of } \\
\text { cases due to } \\
\text { under-registration, } \\
\text { understatement, } \\
\text { and improper } \\
\text { completion of the } \\
\text { fields "occupation" } \\
\text { or "basic cause of } \\
\text { death" is a potential } \\
\text { limitation. } \\
\text { Difficulty in } \\
\text { establishing the } \\
\text { intentionality } \\
\text { behind violent } \\
\text { actions, the } \\
\text { classification } \\
\text { has a degree of } \\
\text { inaccuracy. }\end{array}$ \\
\hline $\begin{array}{c}\text { Almanzar S } \\
\text { et al., } 2014 \text { [3] }\end{array}$ & $\begin{array}{l}\text { Knowledge of } \\
\text { and attitudes } \\
\text { toward } \\
\text { clinical } \\
\text { depression } \\
\text { among health } \\
\text { providers in } \\
\text { Gujarat, India }\end{array}$ & $\begin{array}{c}700 \\
\text { Gujarati-speaking } \\
\text { women between the } \\
\text { ages of } 18-45 \text { years } \\
\text { who resided in the } \\
\text { Anand district of } \\
\text { Gujarat, India }\end{array}$ & $\begin{array}{l}\text { To conduct a } \\
\text { cross-sectional } \\
\text { study during a } \\
\text { 4-week period } \\
\text { in Gujurat, } \\
\text { India, among } \\
\text { resident } \\
\text { physicians and } \\
\text { workers from } \\
\text { the community } \\
\text { health area, } \\
\text { regarding their } \\
\text { knowledge and } \\
\text { view on clinical } \\
\text { depression. }\end{array}$ & $\begin{array}{l}\text { Most of the } \\
\text { community health } \\
\text { workers could not } \\
\text { easily define clinical } \\
\text { depression, and most } \\
\text { of them mentioned } \\
\text { never hearing about } \\
\text { depression or its } \\
\text { definition. Also, a } \\
\text { small number of } \\
\text { subjects disagreed } \\
\text { that depression } \\
\text { happened only } \\
\text { due to tough } \\
\text { circumstances } \\
\text { (38.2\%) or that those } \\
\text { suffering of it had to } \\
\text { blame themselves only } \\
\text { (47.2\%). }\end{array}$ & $\begin{array}{l}\text { MEDLINE/ } \\
\text { PubMed }\end{array}$ & $\begin{array}{l}\text { Most of the } \\
\text { current } \\
\text { investigations } \\
\text { on the attitudes } \\
\text { toward depression } \\
\text { in India has } \\
\text { shown limited } \\
\text { knowledge } \\
\text { on the causality } \\
\text { nexus, and } \\
\text { a negative } \\
\text { generalized } \\
\text { view regarding } \\
\text { depression and } \\
\text { general mental } \\
\text { illness. These } \\
\text { studies } \\
\text { conducted in } \\
\text { India have } \\
\text { reported } \\
\text { depression } \\
\text { prevalence rates } \\
\text { varying between } \\
21 \% \text { and } 83 \% \text { in } \\
\text { primary care } \\
\text { practices. In } \\
\text { such country, } \\
\text { mental health } \\
\text { services are limited. }\end{array}$ \\
\hline
\end{tabular}




\section{Continued}

Cross-sectional study of

Jiao Y et al., attitudes about 2014 [27]
187 psychiatrists from six psychiatric hospitals in Shanghai.
We have used the Scale of Public

Attitudes

About Suicide (SPAS-a

47-item scale developed and validated in

China to assess knowledge psychiatrists in Shanghai
Only $37 \%$ of the psychiatrists agreed correctly that talking about suicide-related issues with an individual would not precipitate suicidal behavior, and only $41 \%$ agreed that those who state that they intend to kill themselves might actually do so. about suicide and seven specific

MEDLINE/

PubMed suicide. The results were compared to those of 548 urban community members

(assessed in a previous study).
The internal consistency measures of the SPAS

(Scale of Public

Attitudes About Suicide)

subscales,

which were

assessed based

on the sample

of psychiatrists, were satisfactory,

but test-retest

reliability

of the scale

was not

assessed.

Hospitals

were not

chosen

randomly

from all

psychiatric

institutions in

Shanghai.

The sample

of the

community

used for

comparison

with the

Shanghai

psychiatrists

was collected

in Tianjin;

thus, Tianjin

results might

not be the

same as of

residents

from the

community in

Shanghai.

The number

of demographic

variables

collected

on the

responders

was limited.

Only three

specific

knowledge-related items

are

considered

in the SPAS. 


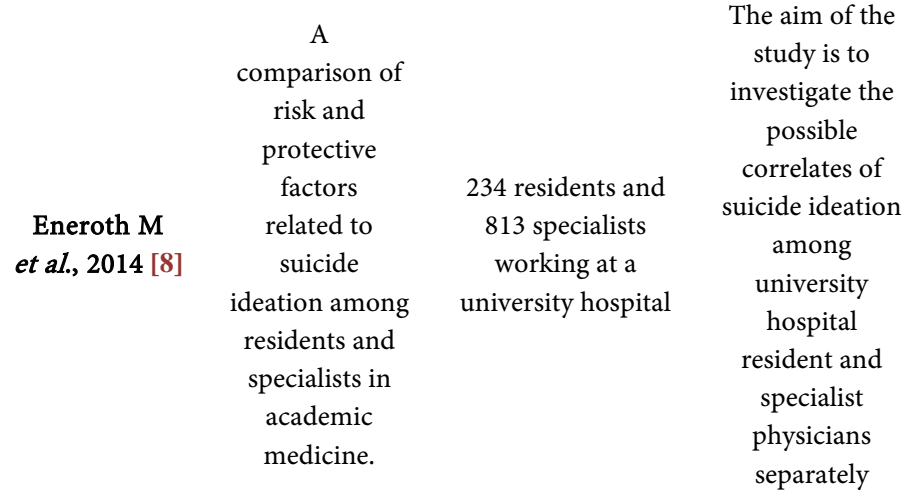

Burnout among

USA medical

students,

residents, and

early career

physicians

relative to the

general USA

population
26,760 medical students and 20,475 residents/fellows in all specialty fields
Logistic regression analysis showed that having supportive meetings was associated with lower level of suicidal ideation among specialists, while an empowering

leadership was related to a lower level of suicidal ideation among residents.

Having been harassed at work was associated with suicidal ideation addition, sickness presenteeism and work disengagement were associated with suicidal ideation in both groups of physicians. among specialists. In

The aim of this study was to compare the prevalence of "burnout" and other forms of distress across career stages and the experiences of trainees and early career physicians versus college undergraduates of similarly age pursuing other careers.
Training seems to be the peak for stress among physicians, but differences in the prevalence of burnout, depressing symptoms, and recent suicidal ideation is relatively small. At each stage, burnout is more prevalent among physicians than among the general population of the USA.

\section{MEDLINE/}

PubMed

Pubred

Analysis stratified by gender is called for in continued research on suicidal ideation among university hospital physicians.

This study was based on cross-sectional data. The possibility of making causal interpretations of the findings is therefore limited. Data on result, work and health-related variables were all obtained from the same questionnaire. Furthermore, extensive communication on suicide thoughts among physicians seemed unlikely to happen due to the stigmatization associated with mental illness.

In comparison with response rates from other national survey studies of physicians and Medicine students, only $23 \%$ to $35 \%$ received an

MEDLINE/ PubMed invitation to take part in this study. It was not possible to determine if the level of difficulty among

non-responders was different due to age, gender or specialty. 


\begin{tabular}{|c|c|c|c|c|c|c|}
\hline $\begin{array}{c}\text { Rosta J, } \\
\text { Aasland OG., } \\
2013[20]\end{array}$ & $\begin{array}{l}\text { Changes in the } \\
\text { lifetime } \\
\text { prevalence of } \\
\text { suicidal } \\
\text { feelings and } \\
\text { thoughts } \\
\text { among } \\
\text { Norwegian } \\
\text { doctors from } \\
2000 \text { to 2010: a } \\
\text { longitudinal } \\
\text { study based on } \\
\text { national } \\
\text { samples }\end{array}$ & $\begin{array}{l}1600 \text { Norwegian } \\
\text { physicians and } \\
3295 \text { German } \\
\text { hospital doctors }\end{array}$ & $\begin{array}{l}\text { The main aims } \\
\text { of this study are } \\
\text { to describe } \\
\text { changes in the } \\
\text { lifetime } \\
\text { prevalence of } \\
\text { suicidal feelings } \\
\text { from } 2000 \text { to } \\
2010 \text { and the } \\
\text { possible } \\
\text { predictors of } \\
\text { serious suicidal } \\
\text { thoughts in } \\
2010 \text { among } \\
\text { Norwegian } \\
\text { physicians. }\end{array}$ & $\begin{array}{l}\text { Suicidal feelings } \\
\text { among Norwegian } \\
\text { physicians decreased } \\
\text { from } 2000 \text { to } 2010 . \\
\text { Individual and } \\
\text { work-related factors } \\
\text { may certainly explain } \\
\text { these findings. In } \\
\text { comparison with } \\
\text { other professionals in } \\
\text { Norway and } \\
\text { physicians in } \\
\text { Germany, Norwegian } \\
\text { physicians showed } \\
\text { higher risks of suicidal } \\
\text { thoughts. }\end{array}$ & $\begin{array}{l}\text { MEDLINE/ } \\
\text { PubMed }\end{array}$ & $\begin{array}{c}\text { Differences in } \\
\text { methodology limit } \\
\text { direct comparisons } \\
\text { with other studies. }\end{array}$ \\
\hline $\begin{array}{c}\text { Gold KJ, Sen } \\
\text { A, Schwenk } \\
\text { TL., } 2013 \text { [15] }\end{array}$ & $\begin{array}{c}\text { Details on } \\
\text { suicide among } \\
\text { US physicians: } \\
\text { data from the } \\
\text { National } \\
\text { Violent Death } \\
\text { Reporting } \\
\text { System }\end{array}$ & $\begin{array}{l}\text { 31,636 suicide } \\
\text { victims, of whom } \\
203 \text { were identified } \\
\text { as physicians. }\end{array}$ & $\begin{array}{l}\text { Data from the } \\
\text { United States } \\
\text { National } \\
\text { Violent Death } \\
\text { Reporting } \\
\text { System were } \\
\text { used to evaluate } \\
\text { demographics, } \\
\text { mental health } \\
\text { variables, } \\
\text { recent stressors } \\
\text { and suicide } \\
\text { methods } \\
\text { among } \\
\text { physicians } \\
\text { versus suicide } \\
\text { victims in } 17 \\
\text { states. }\end{array}$ & $\begin{array}{l}\text { Mental illness is an } \\
\text { important } \\
\text { comorbidity for } \\
\text { physicians who } \\
\text { commit suicide, but } \\
\text { postmortem } \\
\text { toxicology data show } \\
\text { low rates of } \\
\text { medication treatment. } \\
\text { Inadequate treatment } \\
\text { and increased } \\
\text { problems related to } \\
\text { job stress may be } \\
\text { potentially modifiable } \\
\text { risk factors to reduce } \\
\text { suicidal death among } \\
\text { physicians. }\end{array}$ & $\begin{array}{l}\text { MEDLINE/ } \\
\text { PubMed }\end{array}$ & $\begin{array}{l}\text { It is probable } \\
\text { that the used } \\
\text { method } \\
\text { has an } \\
\text { understatement } \\
\text { about the } \\
\text { real incidence } \\
\text { of mental } \\
\text { illness, depression } \\
\text { and its } \\
\text { precipitating } \\
\text { circumstances, } \\
\text { since the victim } \\
\text { cannot be } \\
\text { interviewed } \\
\text { on data } \\
\text { prevenient } \\
\text { from National } \\
\text { Violent Death } \\
\text { Reporting } \\
\text { System. The } \\
\text { significant } \\
\text { stigma } \\
\text { associated } \\
\text { with mental } \\
\text { illness can } \\
\text { also result in } \\
\text { understatement. } \\
\text { Post-mortem } \\
\text { data allow the } \\
\text { description of } \\
\text { associations } \\
\text { between } \\
\text { suicide and } \\
\text { mental illness } \\
\text { and stress, } \\
\text { but they do not } \\
\text { enable } \\
\text { investigators to } \\
\text { identify a causal } \\
\text { relation. }\end{array}$ \\
\hline
\end{tabular}




\section{Continued}

$\begin{array}{cc} & \text { Why don't } \\ & \text { academic } \\ & \text { physicians seek } \\ \text { Fridner A et } & \text { needed } \\ \text { al., 2012 [35] } & \text { professional } \\ & \text { help for } \\ & \text { psychological } \\ & \text { distress? }\end{array}$

Siu C, Yuen

SK, Cheung

A., 2012 [28]
900 Italian

physicians and

841 physicians

from Sweden

distress?
Burnout among public doctors in Hong Kong: cross-sectional survey

$$
\begin{gathered}
\text { Analyses were } \\
\text { performed } \\
\text { among } \\
\text { university } \\
\text { hospital } \\
\text { physicians, } \\
\text { who had } \\
\text { reported }
\end{gathered}
$$

recent suicida

thoughts

and/or showed

other

indications of

current

psychological

disease. These

distressed

physicians were

a subgroup

(42.7\%)

from the

cross-sectional

study (Health and

Organization among

Hospital

Physicians in

Europe): 366

from Sweden

and 150 from

Italy.

One thousand

$(100,000)$

physicians were randomly chosen in the Hong Kong

Public Doctors'

Association

registry.

We assessed the prevalence of burnout among Hong Kong public hospital doctors and correlated burnout with job

characteristics, working hours, phase I HOUPE

University
Few of these

university hospital

physicians with signs

of psychological

distress sought help

from a mental health

professional. This has

implications for

physicians themselves

and for their patients,

for clinical research

and for education of

future physicians.

More studies,

preferably of

interventional design, are warranted concerning help seeking among these physicians in need.

\section{MEDLINE/}

PubMed

PubMed

The study was not capable to know how many of these physicians going through difficulties, who received help in the past, are also receiving the help they currently need. On the other hand, since the GHQ and MOLBI appointments refer to the last weeks, the authors

cannot always expect that psychic suffering last enough to explain care-seeking. Samples are very large and heterogeneous and they include a range of specialists within the academic medical environment.

A great ratio of stressors, and stress-relieving strategies. public doctors

who

responded

to our survey

endured a

high level of

burnout. Trainees with some experience were at higher risk. Stressors identified in this study should be addressed,

so as to improve job satisfaction.
MEDLINE/ The study does not PubMed report limitations. 


$\begin{array}{cc}\text { Aasland OG, } & \text { Mortality } \\ \text { Hem E, } & \text { among } \\ \text { Haldorsen T, } & \text { Norwegian } \\ \text { Ekeberg O., } & \text { doctors } \\ \text { 2011 [26] } & 1960-2000 .\end{array}$

Pan YJ, Lee

$\mathrm{MB}$, Lin CS., 2009 [29]

Physician suicide in

Taiwan, 2000-2008:
The total number of deaths in the study population was $1,583,559$.

1011 deaths with recorded causes in physician insurance records from January 1, 2000 to April 30, 2008. other graduates and the general were compared decade, gender, preliminary findings
To study the mortality pattern of Norwegian physicians, people in human service occupations, population during the period of 1960-2000 by and age.

\section{Physicians}

have a lower mortality rate

than the general population for all causes of death, except suicide. The mortality rates for other undergraduates and human service occupations were $0.7-0.8$ compared with the general population. However, physicians have a higher mortality rate than other undergraduates.

To explore the association between physicians' suicide and their

characteristics, including age, sex, specialties, area of residence, hospital types, and suicide methods
Physicians who committed suicide possibly were aged near 40 years old, served the community, lived in urban areas, and were specialized in Medical Clinical Practice, Family Medicine, Psychiatry, and Surgery.

MEDLINE/

PubMed

Puned


Petersen MR, Burnett CA., 2008 [32]

\section{The suicide mortality of working physicians and dentists}

Which doctors and with what problems contact a specialist service for doctors? A cross-sectional investigation
Using all deaths and corresponding census data in 26 US states from 1984 through 1992, we examine the suicide risk for
Female white women show a higher hate of suicide. Only older male physicians and dentists have a high suicide rate, which partially explains the varied conclusions in literature.
Garelick A

t al., 2007

[21. working
physicians
and dentists. working
physicians
and dentists. working
physicians
and dentists.
22 female physicians
181 male physicians, 61 female dentists and

123 physicians contacted between February 2002 and February 2004

To delineate the characteristics of doctors utilizing the service, to describe their psychological morbidity, and to determine if early intervention is achieved.

\begin{tabular}{|c|c|}
\hline $\begin{array}{l}\text { MEDLINE/ } \\
\text { PubMed }\end{array}$ & $\begin{array}{l}\text { Data do not } \\
\text { allow } \\
\text { separated } \\
\text { calculations } \\
\text { for several } \\
\text { medical } \\
\text { specialties; } \\
\text { therefore, } \\
\text { suicide attempts } \\
\text { could not be } \\
\text { analyzed. } \\
\text { Non-white } \\
\text { male individuals } \\
\text { and female } \\
\text { dentists were } \\
\text { in a small } \\
\text { amount } \\
\text { for the analysis. } \\
\text { 22 deaths } \\
\text { among } \\
\text { female white } \\
\text { physicians } \\
\text { is a reasonably } \\
\text { small number. } \\
\text { The latter was } \\
\text { more than two } \\
\text { times higher } \\
\text { than the expected, } \\
\text { which was } \\
\text { statistically } \\
\text { significant. } \\
\text { Another } \\
\text { limitation } \\
\text { is that death } \\
\text { certificate } \\
\text { data include } \\
\text { habitual } \\
\text { occupation, } \\
\text { whereas census } \\
\text { data include } \\
\text { current } \\
\text { occupation. }\end{array}$ \\
\hline $\begin{array}{l}\text { MEDLINE/ } \\
\text { PubMed }\end{array}$ & $\begin{array}{l}\text { The study presents a } \\
\text { number of } \\
\text { limitations in so far } \\
\text { as it has no control } \\
\text { group and clients } \\
\text { referred themselves } \\
\text { to the service } \\
\text { (although they were } \\
\text { often strongly } \\
\text { encouraged } \\
\text { to do so). }\end{array}$ \\
\hline
\end{tabular}


Suicide in doctors: a study

according to

Hawton $\mathrm{K}$ et al., 2001 [31]

Juel K,

Mosbech J,

Hansen ES.,

1999 [30]
Mortality and causes of death among Danish medical doctors 1973-1992.
Wales,

1979-1995

specialty in

medical

practitioners in

England and of risk gender,

\begin{tabular}{|c|c|c|c|c|c|c|}
\hline $\begin{array}{l}\text { Hawton K et } \\
\text { al., } 2001 \text { [31] }\end{array}$ & $\begin{array}{l}\text { Suicide in } \\
\text { doctors: a study } \\
\text { of risk } \\
\text { according to } \\
\text { gender, } \\
\text { seniority and } \\
\text { specialty in } \\
\text { medical } \\
\text { practitioners in } \\
\text { England and } \\
\text { Wales, } \\
\text { 1979-1995 }\end{array}$ & $\begin{array}{l}\text { Two hundred and } \\
\text { twenty-three (223) } \\
\text { medical } \\
\text { practitioners in } \\
\text { the National Health } \\
\text { Service who died by } \\
\text { suicide or } \\
\text { undetermined } \\
\text { cause }\end{array}$ & $\begin{array}{l}\text { To investigate } \\
\text { the suicide risk } \\
\text { of doctors in } \\
\text { England and } \\
\text { Wales, } \\
\text { according to } \\
\text { gender, } \\
\text { seniority and } \\
\text { specialty }\end{array}$ & $\begin{array}{l}\text { There is a high } \\
\text { risk of suicide } \\
\text { in female } \\
\text { physicians, } \\
\text { but male } \\
\text { physicians } \\
\text { seem to be } \\
\text { at lower risk } \\
\text { than the male } \\
\text { general } \\
\text { population. } \\
\text { There were } \\
\text { significant } \\
\text { differences } \\
\text { between } \\
\text { specialties and } \\
\text { anesthetists, } \\
\text { community } \\
\text { health } \\
\text { physicians, } \\
\text { general } \\
\text { practitioners, } \\
\text { and psychiatrists } \\
\text { having } \\
\text { significantly } \\
\text { increased rates } \\
\text { compared with } \\
\text { physicians from } \\
\text { general hospitals. }\end{array}$ & $\begin{array}{l}\text { MEDLINE/ } \\
\text { PubMed }\end{array}$ & $\begin{array}{l}\text { Suicidal verdicts } \\
\text { were compared with } \\
\text { open verdicts, and } \\
\text { some of them } \\
\text { possibly were not } \\
\text { suicides. Another } \\
\text { limitation is the fact } \\
\text { that, during data } \\
\text { collection, the death } \\
\text { certificate or official } \\
\text { Y records were } \\
\text { considered } \\
\text { information, and in } \\
\text { some cases, they } \\
\text { could be deceiving } \\
\text { or incomplete. }\end{array}$ \\
\hline $\begin{array}{c}\text { Juel K, } \\
\text { Mosbech J, } \\
\text { Hansen ES., } \\
1999[30]\end{array}$ & $\begin{array}{l}\text { Mortality and } \\
\text { causes of death } \\
\text { among Danish } \\
\text { medical doctors } \\
\text { 1973-1992. }\end{array}$ & $\begin{array}{c}21,943 \text { physicians, } \\
6012 \text { of whom } \\
\text { were women. }\end{array}$ & $\begin{array}{l}\text { To examine the } \\
\text { mortality } \\
\text { pattern of } \\
\text { Danish doctors } \\
\text { for the period } \\
\text { 1973-1992 } \\
\text { A historical } \\
\text { prospective } \\
\text { cohort study } \\
\text { based on the } \\
\text { membership } \\
\text { register of the } \\
\text { Danish Medical } \\
\text { Association. }\end{array}$ & $\begin{array}{l}\text { The suicide rate was } \\
\text { increased, mainly due } \\
\text { to the high number of } \\
\text { suicides by poisoning. } \\
\text { Compared with the } \\
\text { general population, } \\
\text { the physicians' } \\
\text { mortality was low, but } \\
\text { the mortality due to } \\
\text { external causes was } \\
\text { increased, mainly due } \\
\text { to an excessive } \\
\text { number of suicides. }\end{array}$ & $\begin{array}{l}\text { MEDLINE/ } \\
\text { PubMed }\end{array}$ & $\begin{array}{l}\text { Data do not } \\
\text { enable to } \\
\text { conclude } \\
\text { if the } \\
\text { difference } \\
\text { among } \\
\text { genders in the } \\
\text { mortality is a } \\
\text { recent or } \\
\text { non-recent } \\
\text { phenomenon. } \\
\text { Only few } \\
\text { women } \\
\text { graduated } \\
\text { in the previous } \\
\text { period of the } \\
\text { century, and } \\
\text { there are significant } \\
\text { differences in the } \\
\text { selection of women } \\
\text { who started } \\
\text { working in such } \\
\text { profession, in the } \\
\text { beginning of the } \\
\text { century, and those } \\
\text { who started within } \\
\text { some years more } \\
\text { recently. }\end{array}$ \\
\hline
\end{tabular}

\begin{tabular}{|c|c|c|c|c|c|c|}
\hline $\begin{array}{l}\text { Hawton K et } \\
\text { al., } 2001 \text { [31] }\end{array}$ & $\begin{array}{c}\text { Suicide in } \\
\text { doctors: a study } \\
\text { of risk } \\
\text { according to } \\
\text { gender, } \\
\text { seniority and } \\
\text { specialty in } \\
\text { medical } \\
\text { practitioners in } \\
\text { England and } \\
\text { Wales, } \\
\text { 1979-1995 }\end{array}$ & $\begin{array}{c}\text { Two hundred and } \\
\text { twenty-three (223) } \\
\text { medical } \\
\text { practitioners in } \\
\text { the National Health } \\
\text { Service who died by } \\
\text { suicide or } \\
\text { undetermined } \\
\text { cause }\end{array}$ & $\begin{array}{l}\text { To investigate } \\
\text { the suicide risk } \\
\text { of doctors in } \\
\text { England and } \\
\text { Wales, } \\
\text { according to } \\
\text { gender, } \\
\text { seniority and } \\
\text { specialty }\end{array}$ & $\begin{array}{l}\text { There is a high } \\
\text { risk of suicide } \\
\text { in female } \\
\text { physicians, } \\
\text { but male } \\
\text { physicians } \\
\text { seem to be } \\
\text { at lower risk } \\
\text { than the male } \\
\text { general } \\
\text { population. } \\
\text { There were } \\
\text { significant } \\
\text { differences } \\
\text { between } \\
\text { specialties and } \\
\text { anesthetists, } \\
\text { community } \\
\text { health } \\
\text { physicians, } \\
\text { general } \\
\text { practitioners, } \\
\text { and psychiatrists } \\
\text { having } \\
\text { significantly } \\
\text { increased rates } \\
\text { compared with } \\
\text { physicians from } \\
\text { general hospitals. }\end{array}$ & $\begin{array}{c}\text { MEDLINE/ } \\
\text { PubMed }\end{array}$ & $\begin{array}{l}\text { Suicidal verdicts } \\
\text { were compared with } \\
\text { open verdicts, and } \\
\text { some of them } \\
\text { possibly were not } \\
\text { suicides. Another } \\
\text { limitation is the fact } \\
\text { that, during data } \\
\text { collection, the death } \\
\text { certificate or official } \\
\text { Y records were } \\
\text { considered } \\
\text { information, and in } \\
\text { some cases, they } \\
\text { could be deceiving } \\
\text { or incomplete. }\end{array}$ \\
\hline $\begin{array}{c}\text { Juel K, } \\
\text { Mosbech J, } \\
\text { Hansen ES., } \\
1999[30]\end{array}$ & $\begin{array}{c}\text { Mortality and } \\
\text { causes of death } \\
\text { among Danish } \\
\text { medical doctors } \\
\text { 1973-1992. }\end{array}$ & $\begin{array}{c}21,943 \text { physicians, } \\
6012 \text { of whom } \\
\text { were women. }\end{array}$ & $\begin{array}{l}\text { To examine the } \\
\text { mortality } \\
\text { pattern of } \\
\text { Danish doctors } \\
\text { for the period } \\
1973-1992 \\
\text { A historical } \\
\text { prospective } \\
\text { cohort study } \\
\text { based on the } \\
\text { membership } \\
\text { register of the } \\
\text { Danish Medical } \\
\text { Association. }\end{array}$ & $\begin{array}{l}\text { The suicide rate was } \\
\text { increased, mainly due } \\
\text { to the high number of } \\
\text { suicides by poisoning. } \\
\text { Compared with the } \\
\text { general population, } \\
\text { the physicians' } \\
\text { mortality was low, but } \\
\text { the mortality due to } \\
\text { external causes was } \\
\text { increased, mainly due } \\
\text { to an excessive } \\
\text { number of suicides. }\end{array}$ & $\begin{array}{l}\text { MEDLINE/ } \\
\text { PubMed }\end{array}$ & $\begin{array}{l}\text { Data do not } \\
\text { enable to } \\
\text { conclude } \\
\text { if the } \\
\text { difference } \\
\text { among } \\
\text { genders in the } \\
\text { mortality is a } \\
\text { recent or } \\
\text { non-recent } \\
\text { phenomenon. } \\
\text { Only few } \\
\text { women } \\
\text { graduated } \\
\text { in the previous } \\
\text { period of the } \\
\text { century, and } \\
\text { there are significant } \\
\text { differences in the } \\
\text { selection of women } \\
\text { who started } \\
\text { working in such } \\
\text { profession, in the } \\
\text { beginning of the } \\
\text { century, and those } \\
\text { who started within } \\
\text { some years more } \\
\text { recently. }\end{array}$ \\
\hline
\end{tabular}




$\begin{array}{ccc} & \begin{array}{c}\text { Mortality of } \\ \text { doctors in }\end{array} & 18,358 \text { male and } \\ & \text { different } & \text { 2168 female NHS } \\ \text { Carpenter LM, } & \text { specialties: } & \text { hospital consultants } \\ \text { Swerdlow AJ, } & \text { findings from a } & \text { employed in } \\ \text { Fear NT., } & \text { cohort of } & \text { England and } \\ \text { 1997 [33] } & \text { 20,000 NHS } & \text { Wales, between } \\ & \text { hospital } & 1962 \text { and 1979. } \\ & \text { consultants } & \end{array}$

Mortality of cohort of ,000 NHS consultants
To examine patterns of cause specific mortality in NHS hospital consultants according to their specialty and to assess these in the context of potential occupational exposures.

A historical cohort assembled from the Department of Health records with follow-up through the NHS Central Register.
The increased risks of accidental poisoning in male physicians,

and of suicide in female physicians, are of concern, better prevention measures

MEDLINE/

PubMed are therefore necessary.
With some few exceptions, there were small pieces of evidence to suggest that any of the analyzed specialties experienced higher or lower mortality rates than those of other male or female physicians.

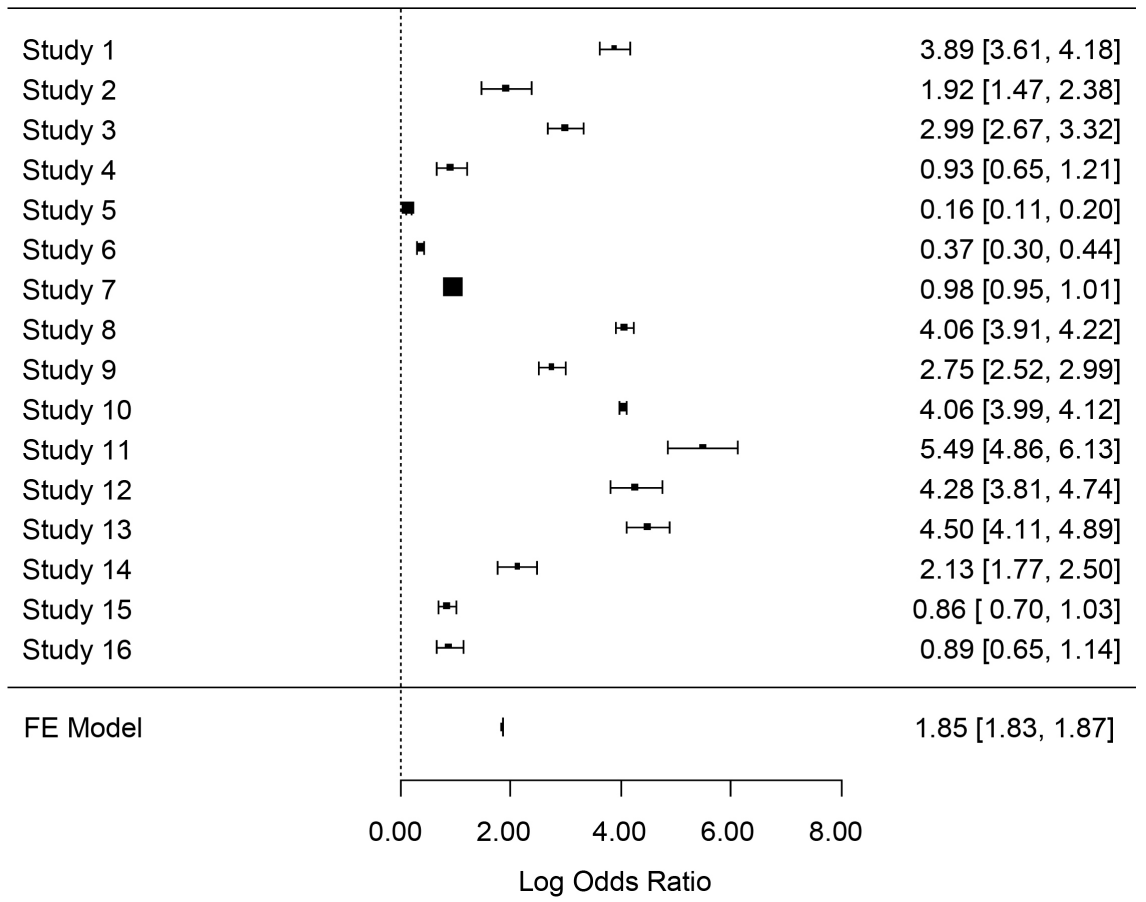

Figure 2. Statistical analysis of the studies. Source: Developed by the authors (2016).

\section{Discussion}

\subsection{Database Comparison}

The scientific information available in electronic bibliographic databases with 
open access to references and full texts has been a well-known tool of support to make clinical decisions, and also in the constant search to update and qualify health professionals [37].

The square represents the effect of studies and the line indicates the confidence interval. The size of squares represents the weight of each group of studies for the statistical analysis. The vertical line shows the absence of effect, and Fixed-Effects (FE) symbolize the result of the analysis.

Thus, the Health Sciences area and its unfolding in Collective Health have been facing important scientific challenges seeking social health and welfare, including the interdependence of knowledge. Then, the relevance of free availability of scientific information (Open Access) in bibliographic databases supports the sustainability of sciences and health professionals' development, because it helps the development, preservation, spreading, access, and use of scientific information without costs, including health information systems [38].

\subsection{Introduction}

Health professionals have high performance expectations. Job positions in these areas are necessarily stressful, which might lead to adverse effects on health [21].

Indeed, the healthy worker's effect refers to a consistent trend of the active employee in having a lower mortality rate than the general population due to selection effects [8] [11]. However, this is not applied to physicians, regarding death by suicide. In comparison with other occupations [8] [12] [22], other university graduates [8] [23] and people in general [8] [24] [25], suicide and suicidal thoughts are significantly more common among physicians, as well as burnout and other signs of psychic suffering. Mortality rate by almost all causes of death, except suicide, is however lower for physicians than for the general audience [8] [26], which is in agreement with the healthy worker's effect [8].

In addition, precipitating factors are comprised of reduction of the risk of a recent loss or crisis and increase of risk of a job problem that might reflect the experience of a physician in dealing with death and loss, but inability of dealing with problems related with a physician's identity. Medical self-identification is centered many times on the professional role, which can pass through job aspects and their lives at home. For someone whose job helps defining and identifying his/her personal and professional profile, crisis in a job situation can make him/her feel more threatened than for someone whose personal identity depended less on job satisfaction [15].

Although speculative, medical suicide rate is believed to be higher than the reported rate, since it can be poorly codified in death certificates, sometimes deliberately. For instance, a death can be notified as an accidental overdose of a distracting prescription drug or medicine, instead of a purposeful overdosing [15].

Under these circumstances, the study of Jiao Y and collaborators compared the points of view of members from a community to psychiatrists' in Shanghai, China, regarding the posture of these populations before suicide. They found 
that although physicians considered suicide as a preventable worldwide public health social issue, they had stigmatized views about the suicidal patient and comprehended such patient less with lower sympathy. Even after filtering sociodemographic characteristics, the analysis remained significant [27].

\subsection{Epidemiology}

In a certain article, only $14.9 \%$ of the responders were satisfied or very satisfied with their jobs, whereas $52.5 \%$ were dissatisfied or very dissatisfied with their jobs. Almost a tenth of the physicians had had suicidal thoughts, although none had tried committing suicide [28].

Furthermore, physicians, other university graduates and human services professionals presented a lower rate and decrease of mortality compared with the general population [26]. Therefore, regarding specific causes of death, physicians had a higher mortality suicide rate than the general population [26].

In another study, there were 17 defined and 15 possible suicides. Among the 17 defined cases, 16 were of the male gender. $70.6 \%$ of these individuals died at the age of 40 and other $11.8 \%$ were 51 to 64 years old when they died. Only $17.6 \%$ of the subjects were aged $\leq 40$ years when they died. Among the cases of defined suicide [29], the most frequent suicide methods were hanging/asphyxia $(\mathrm{n}=5,29.4 \%)$, vegetal charcoal burning $(\mathrm{n}=5,29.4 \%)$, and drug poisoning $(\mathrm{n}=$ $5,23.5 \%)$.

Thus, results showed a consistent increase of suicide mortality with a standardized mortality ratio around 1.65 , mainly due to the excessive number of suicides by poisoning [30]. Suicide verdicts had been provided by $87 \%$ of the remaining 223 physicians and open verdicts by $13 \%$ of them [31]. A cohort study identified that therapists considered $42 \%$ of the physicians at risk [21].

Responders showing the highest burnout rates were younger physicians that had worked for about 8.5 years, period in which they were still taking or had just concluded training with specialists [28]. These young physicians, with moderate experience and who needed to work during shifts, seemed more vulnerable [28].

Thereby, physicians who committed suicide had higher chances of being 40 years old, of serving the community and of living in urban areas. Additionally, a study found a predominance of medical suicide among physicians serving the community [29].

Another study has showed that no specific cause was highlighted for female death, only suicide. In general, mortality rate indices were quite similar for men and women. This indicates that educational level and health behavior explain differences in mortality rather than gender, with exception of specific genderrelated illnesses [26].

Although the suicide rate of white women was only around half of the high rate compared to their male colleagues, such rate was approximately twice higher than the normal working population [32]. These female physicians had a Suicide Rates Ratio (SRR) of 52.10 compared with working professionals, which was still statistically high [32]. 
Female physicians presented higher suicide rates than the standard population in almost all age groups, and the elevations were statistically significant in some cases. The high amount of suicide rate for females also increased with age $(\mathrm{p}=$ 50.015) [32]. The suicide rate for females was higher than that for the active female population from the USA [32].

Besides, there was a strong trend of suicide rate increase for male physicians with age increase [32]. This is important because some studies indicate that white male physicians $>45$ years have higher rates of suicide, whereas those aged 45 or less present decreased ones [32].

The female physicians' suicide ratio is another remarkable finding. Women comprised around $13.2 \%$ of the total sample and $24 \%$ of the suicide death group; thus, they are represented in the suicide group $(p=0.02)$. This result does not reflect the suicide rate of the Brazilian population, in which males are 2.3 to 4.0 times at higher risk [5].

Nevertheless, with regard to the psychiatry service, there is a quite similar amount of male and female physicians in general, and no differences were found in the degree of morbidity [21]. There was no difference in gender distribution in the two verdict categories [31]. The youngest age range of both genders presented relatively high rates [31]. The largest group of physicians was comprised of specialists with medical registration (residents), who were concluding their under graduation course; therefore, they were looking for consultant positions (specialist staff), and there was a significant number of new consultants [21].

The main exception to the low mortality rate among female physicians was almost twice higher than mortality rate due to injuries and poisoning. This was mainly attributed to an excessive amount of suicides, mainly of female anesthetists [33]. It has been found that mortality rates in male specialist physicians were also lower in men from the I social class [33], considered "High-Level Professionals and business workers".

Agreeing these ideas, one of the most stressful moments for residents is the transition from being resident to being completely responsible [21]. Most of the responders had concluded their graduation tests, academic performance was therefore not compromised [21].

Four specialties presented significantly higher suicide rates than the general medicine, as follows by order of risk: community health, anesthesiology, psychiatry, and general practice. The pattern of suicide rates by gender and time period was similar in almost all specialties, but the community health that had a male rate of 12.3 times higher than women [31]. Psychiatrists showed a significantly higher global mortality rate compared to all the other specialized physicians, with significant high rates of poisoning, for instance [33].

The total suicide mortality rate was significantly increased. An increase of suicide frequency by poisoning was a common characteristic seen in all subgroups, especially among male members of the Association of Specialist Physicians (AMS, acronym in Portuguese) and of the Organization of Practicing Physicians (OGP). Physicians presented an increase in the number of accidents and suicides 
by poisoning, as well as by other methods [30].

\subsection{Risk Factors}

Some articles approached through multivariate, comparative or descriptive analyses [27] [28] [29] [33] [34] the possible risk factors that could develop high levels of emotional overload and, as consequence, genesis of suicidal ideations among physicians. A study carried out in Taiwan, published in 2009, points out that the highest rates of emotional disorders among physicians occur at the age of 40 years, a moment when physicians have gone through a relative extenuating working period and, therefore, believe they are less capable of taking new personal and professional directions [29].

However, Siu, Yuen and Cheung, 2012, after analyzing 226 questionnaires applied to physicians enrolled in the Hong Kong Public Doctors' Association, observed that higher levels of physical and emotional burnout were associated with early age, less working experience, need of job shift changes, less children, and lower physical workout [28]. In compliance with the outcomes of this study, Dyrbye and collaborators (2014) showed that depressing symptoms, as well as general burnout, depersonalization and intense fatigue were more commonly found among Medicine students and residents compared with the general prevalence rates of these symptoms in the North-American population of the same age, which decreased after development in the professional career stages [34]. This result is similar to what was seen by Eneroth $M$ and collaborators, 2014, who also pointed out as causes of suicidal ideation: job concern, frequent meetings to discuss experiences and demands, sick presenteeism and job disengagement [8].

Carpenter L, Swerdlow A and Fear N, 1997, showed that adverse job conditions with long working hours and task overload are also important in this condition, since they have a direct impact on the professional's job quality [33]. The amount of hours spent by a medical professional for the genesis of this situation is around 56, in a way that burnout among physicians is possibly related to a wide interaction of factors, including physical exhaustion, too many shifts, unhealthy working positions and unhealthy sleep patterns [28]. Additionally, the combination of extenuating working conditions and possible selection of subjects with particular personality marks might contribute to high risks of suicide among physicians [15] [20] [30]. Siu, Yuen and Cheung, 2012, reported that physical exercises and colleagues' social support were not considered factors of burnout relief [28], and the culture the physicians undergone did not have so much importance as a risk factor for the genesis of suicidal thoughts [20].

In general, inappropriate handling, increase of work-related issues and stress seem to be risk factors, which can be the key to decrease deaths by suicide among physicians when dealt correctly [5]. This can also be done through the positive influence on the job environment, with leaders able to teach and ask correctly for such physicians, since these influences were considered to have a positive impact on the resident's professional and personal lives [8] (Figure 3 


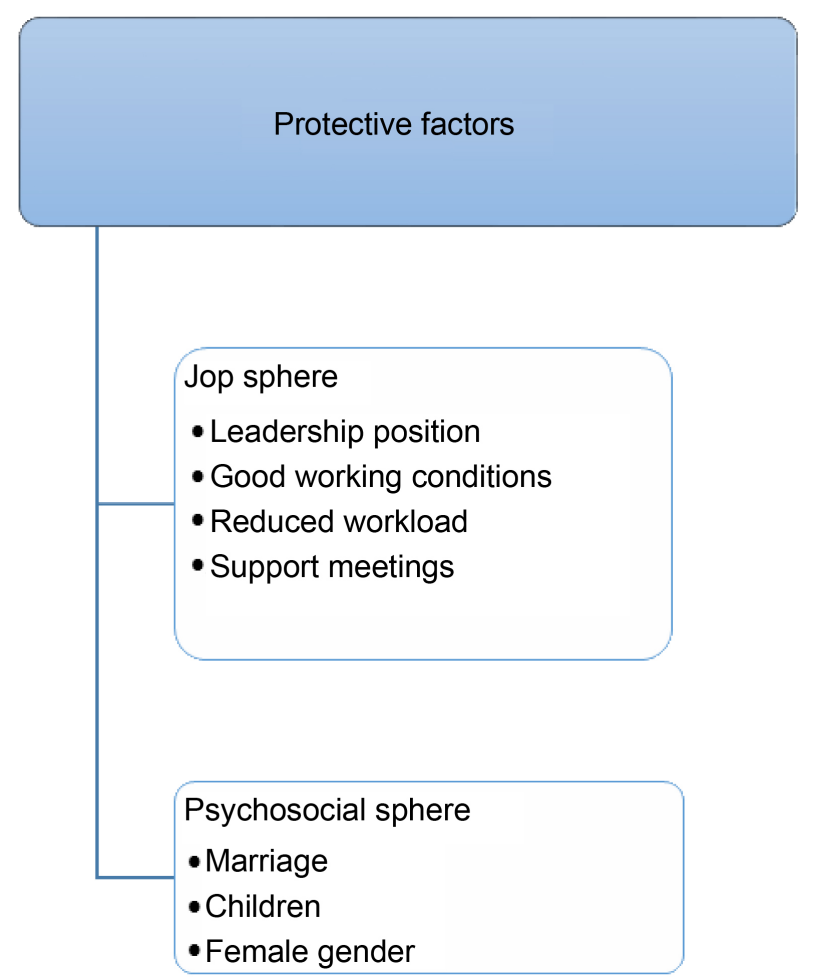

Figure 3. Protection factors against suicide among physicians, based on the analyzed studies. Source: Developed by the authors (2016).

and Figure 4).

These factors were compared through the Pearson Linear Correlation Graph, in order to better clarify the relationship between these elements and suicide among physicians. The correlation coefficient found was 0.89 , which indicates a strong relation between these variables (Figure 5).

\subsection{Impact on Public Health and on the Individual's Professional Health}

Several analyzed studies indicate that suicide among physicians, as well as actions that resulted in this condition, was harmful not only to the career of the professional facing this situation, but also to the provision of health to the general population [5] [28].

Gold K, Sen A and Schwenk T, 2012, approach that the physician's self-identity is almost always focused on his/her professional role, which has a result in his/her working and personal life. Thus, a crisis at work could be more threatening to a physician than to those whose personal identity is less dependent on job satisfaction [15].

\subsection{Measures to Be Implemented-Family-Seek Support}

Several measures can be taken to avoid conditions that lead to the practice of suicide among physicians, such as: initiatives to decrease workload-related stress, provide job prestige and supply good practices of job safety are viable 


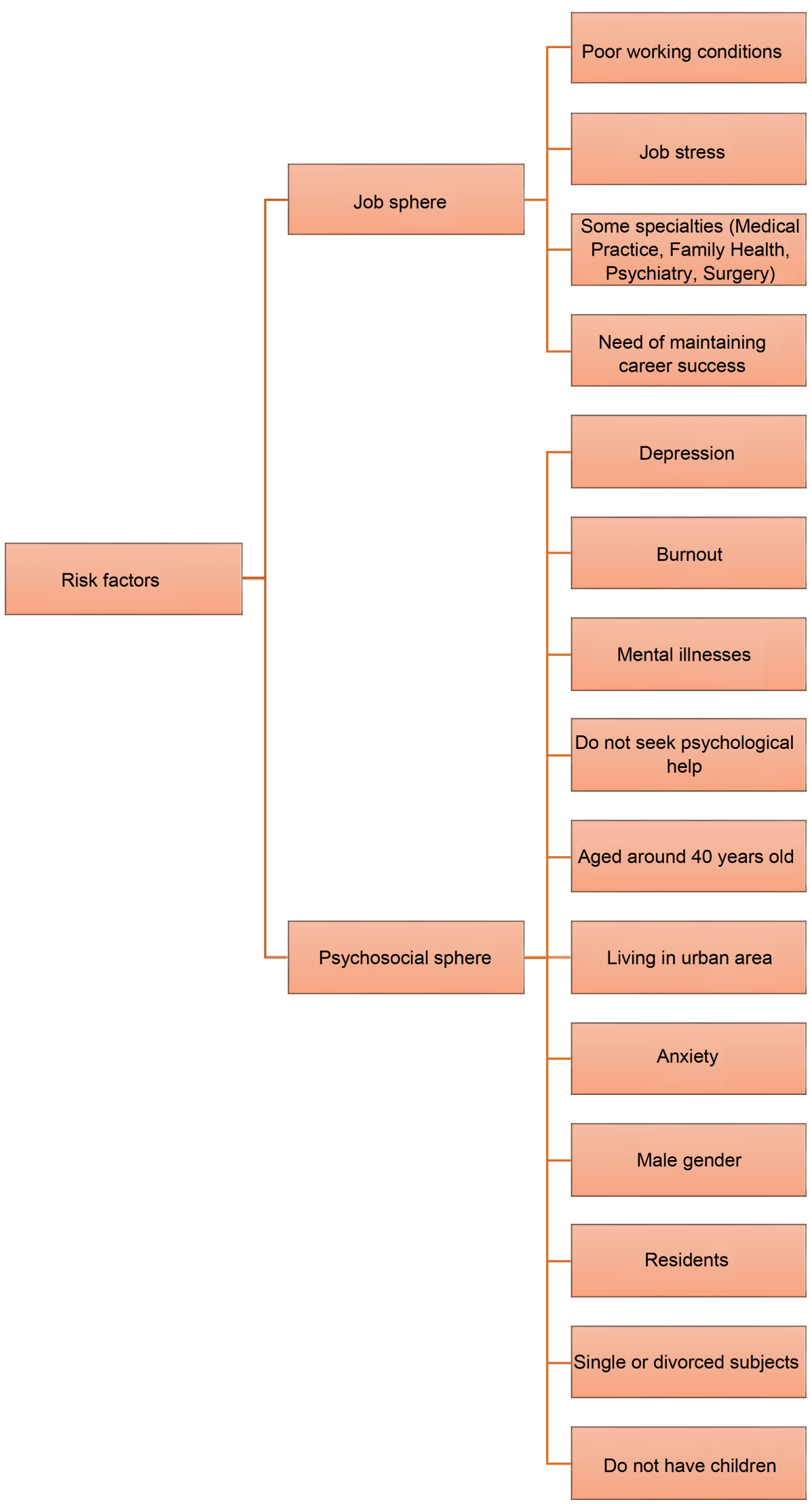

Figure 4. Risk factors for suicide among physicians based on the reviewed studies. Source: Developed by the authors (2016). 


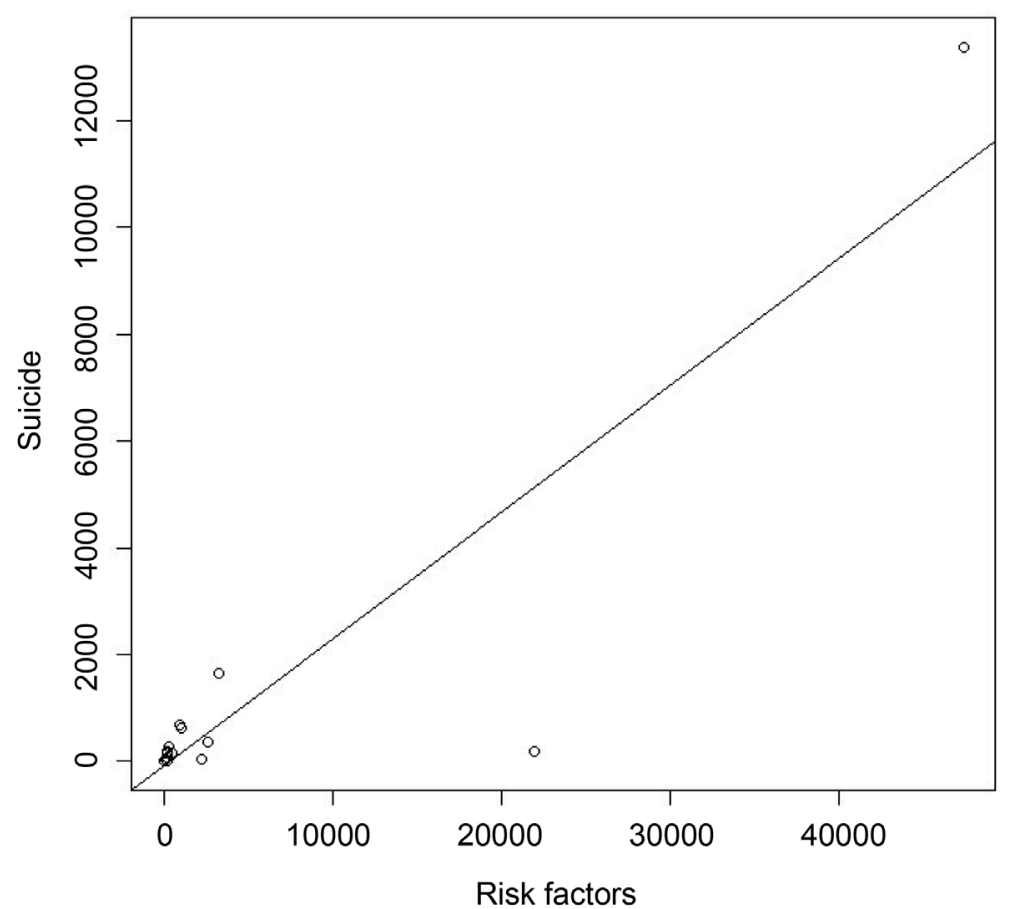

Figure 5. Pearson linear correlation graph presenting the correlation analysis between the risk factors and suicide among physicians. Source: Developed by the authors (2017).

choices [26], since job satisfaction becomes a need [28]. Hence, building connection networks and promoting mutual support among physicians in the community are essential to the medical professional's welfare [29]. There must be strategies focused on improving inter-professional relations, as well as encouraging physicians to seek help in the event of depression, burnout or other emotion$\mathrm{al} /$ mental issue [29].

In addition, some studies indicate an association between being single and/or divorced with suicide, which shows the role of family support in detecting and treating predispositions to such practice. We also known that compared to the general population with the same cause of death, physicians who committed suicide have a higher incidence of mental illnesses associated with working issues [28]. However, other studies observed that only the factor "amount of children" is related to suicide, and the physician's age or marital status had no importance. All the same, this relevance was noticed only among resident male physicians. We assumed that family support, whether from a companion or children or other person who provides emotional support, might be important in the prevention of such problem [8].

Furthermore, another factor of concern is the poor seek of support by medical professionals. The depression-related stigma and lack of knowledge about it hinder millions of people of seeking proper medical support in the correct time period, which result in stress and burnout, as well as in high mortality and morbidity rates, since it not only affects the person committing suicide, but also his/her family. 
Although the mental illness-related stigma is usual, it is more frequently seen in developing and underdeveloped countries [3]. A study found three workrelated characteristics that are also related to the fact of not seeking help for depression: being currently involved in a medical research, being a surgeon and working at night shifts. On the other hand, no significant associations between seeking help and conflict of job functions, job and family conflicts, long working hours and, even, illness were found [35]. For a better understanding on this subject, knowledge on how to develop a healthy lifestyle and the elimination of risk factors are necessary, which might explain the mortality patterns among physicians by suicide [26].

Another study showed that physicians use higher rates of anti-psychotic, benzodiazepines and barbiturates. A physician can get these medicines more easily. Additionally, suicide attempts by overdose in these people are considered less prevalent than by fire gun or hanging. Nonetheless, among physicians who know about the toxicological effects and doses for specific medications, an overdose can represent a greater risk [15]. This reinforces the idea of improving welfare in all career phases as a need [34]. Resident male physicians mostly need support, because they have more difficulties in discussing this kind of problem openly. Thus, individual talks might be more advantageous to them [8].

Thus, despite many factors that contribute to suicide among physicians, a study found that poor working conditions of many of these professionals and unusual routine to which they undergo are the greatest reasons for mental illnesses and other disorders that might result in suicide [20]. A possible strategy to decrease suicide among physicians would be regular screenings in the search of mental illnesses among them, which is characterized as a health policy [20]. In addition, meetings to approach working situations could contribute to decrease of suicidal thoughts [8]. Hence, a Norwegian study showed decrease of suicidal thoughts among male physicians in Norway during the last 10 years, due to the improvement of their working conditions, provided through health system reforms that were implemented in the last decade in such country [20] [36]. We understand that measures like these are important not only to medical professionals, but also to the general population, because the good condition of physicians health is also important to their patients [26].

\section{Conclusions}

Therefore, this study intends to occupy an empty space in scientific knowledge, considering that the access to scientific and technical information is present as an essential characteristic for the development of health research and that the act of sharing the available resources in both analyzed databases presents common methodologies. Such tools of open access research are seen as reliable tools to collect the available scientific content through open access to the available indexed content regarding the methodological characteristics, as well as the scope of recovery of the available information in the bibliographic databases of open access to the full content: MEDLINE/PubMed and BVS/BIREME. 
Scarce recovery of the indexed articles in the analyzed databases is considered a limiting factor of this study, because of the small amount of publications on the theme, especially in the public health context for the theoretical basis on the theme "Suicide among Physicians", which may have hindered carrying out this research. Further studies are recommended in order to extend the research universe by associating the researched theme with the medicine students' category.

\section{References}

[1] World Health Organization (2008) The Global Burden of Disease: 2004 Update. World Health Organization, Geneva.

[2] World Health Organization (2012) Depression. Media Centre Fact Sheet No. 369.

[3] Almanzar, S., et al. (2014) Knowledge of and Attitudes toward Clinical Depression among Health Providers in Gujarat, India. Annals of Global Health, 80, 89-95.

https://doi.org/10.1016/j.aogh.2014.04.001

[4] Bertolote, J.M. and De Leo, D. (2012) Global Suicide Mortality Rates-A Light at the End of the Tunnel? Crisis, 33, 249-253.

https://doi.org/10.1027/0227-5910/a000180

[5] Palhares-Alves, H.N., Palhares, D.M., Laranjeira, R., Nogueira-Martins, L.A. and Sanchez, Z.M. (2015) Suicide among Physicians in the State of São Paulo, Brazil, across one Decade. Revista Brasileira de Psiquiatria, 37, 146-149.

https://doi.org/10.1590/1516-4446-2014-1534

[6] Casey, P., Dunn, G., Kelly, B.D., Lehtinen, V., Dalgard, O.S., Dowrick, C., et al. (2008) The Prevalence of Suicidal Ideation in the General Population: Results from the Outcome of Depression International Network (ODIN) Study. Social Psychiatry and Psychiatric Epidemiology, 43, 299-304.

https://doi.org/10.1007/s00127-008-0313-5

[7] Kessler, R.C., Borges, G. and Walters, E.E. (1996) Prevalence of and Risk Factors for Lifetime Suicide Attempts in the National Comorbidity Survey. Archives of General Psychiatry, 56, 617-626. https://doi.org/10.1001/archpsyc.56.7.617

[8] Eneroth, M., Gustafsson Sendén, M., Løvseth, L.T., Schenck-Gustafsson, K. and Fridner, A. (2014) A Comparison of Risk and Protective Factors Related to Suicide Ideation among Residents and Specialists in Academic Medicine. BMC Public Health, 14, 271. https://doi.org/10.1186/1471-2458-14-271

[9] Stack, S. (2004) Suicide Risk among Physicians: A Multivariate Analysis. Archives of Suicide Research, 8, 287-292. https://doi.org/10.1080/13811110490436954

[10] Scocco, P., de Girolamo, G., Vilagut, G. and Alonso, J. (2008) Prevalence of Suicide Ideation, Plans, and Attempts and Related Risk Factors in Italy: Results from the European Study on the Epidemiology of Mental Disorders-World Mental Health Study. Comprehensive Psychiatry, 49, 13-21.

https://doi.org/10.1016/j.comppsych.2007.08.004

[11] McMichael, A.J. (1976) Standardized Mortality Ratios and the "Healthy Worker Effect" : Scratching Beneath the Surface. Journal of Occupational Medicine, 18, 165168. https://doi.org/10.1097/00043764-197603000-00009

[12] Agerbo, E., Gunnell, D., Bonde, J.P., Mortensen, P.B. and Nordentoft, M. (2007) Suicide and Occupation: The Impact of Socio-Economic, Demographic and Psychiatric Differences. Psychological Medicine, 37, 1131-1140. https://doi.org/10.1017/S0033291707000487

[13] Dyrbye, L.N., Thomas, M.R. and Shanafelt, T.D. (2006) Systematic Review of De- 
pression, Anxiety, and Other Indicators of Psychological Distress among US and Canadian Medical Students. Academic Medicine, 81, 354-373. https://doi.org/10.1097/00001888-200604000-00009

[14] Dyrbye, L.N., et al. (2011) Patterns of Distress in US Medical Students. Medical Teacher, 33, 834-839. https://doi.org/10.3109/0142159X.2010.531158

[15] Gold, K.J., Sen, A. and Schwenk, T.L. (2013) Details on Suicide among US Physicians: Data from the National Violent Death Reporting System. General Hospital Psychiatry, 35, 45-49. https://doi.org/10.1016/j.genhosppsych.2012.08.005

[16] Gagné, P., Moamai, J. and Bourget, D. (2011) Psychopathology and Suicide among Quebec Physicians: A Nested Case Control Study. Depression Research and Treatment, 2011, Article ID: 936327. https://doi.org/10.1155/2011/936327

[17] Frank, E. and Dingle, A.D. (1999) Self-Reported Depression and Suicide Attempts among US Women Physicians. American Journal of Psychiatry, 156, 1887-1894.

[18] Center, C., et al. (2003) Confronting Depression and Suicide in Physicians: A Consensus Statement. JAMA, 289, 3161-3166. https://doi.org/10.1001/jama.289.23.3161

[19] TD, S., et al. (2011) Special Report: Suicidal Ideation among American Surgeons. Archives of Surgery, 146, 54-62. https://doi.org/10.1001/archsurg.2010.292

[20] Rosta, J. and Aasland, O.G. (2013) Changes in the Lifetime Prevalence of Suicidal Feelings and Thoughts among Norwegian Doctors from 2000 to 2010: A Longitudinal Study Based on National Samples. BMC Psychiatry, 13, 322. https://doi.org/10.1186/1471-244X-13-322

[21] Garelick, A.I., et al. (2007) Which Doctors and with What Problems Contact a Specialist Service for Doctors? A Cross Sectional Investigation. BMC Medicine, 5, 26. https://doi.org/10.1186/1741-7015-5-26

[22] Frank, E., Biola, H. and Burnett, C.A. (2000) Mortality Rates and Causes among US Physicians. American Journal of Preventive Medicine, 19, 155-159. https://doi.org/10.1016/S0749-3797(00)00201-4

[23] Hem, E., et al. (2005) Suicide Rates According to Education with a Particular Focus on Physicians in Norway 1960-2000. Psychological Medicine, 35, 873-880. https://doi.org/10.1017/S0033291704003344

[24] Lindeman, S., Laara, E., Hakko, H. and Lonnqvist, J. (1996) A Systematic Review on Gender-Specific Suicide Mortality in Medical Doctors. British Journal of Psychiatry, 168, 274-279. https://doi.org/10.1192/bjp.168.3.274

[25] Schernhammer, E.S. and Colditz, G.A. (2004) Suicide Rates among Physicians: A Quantitative and Gender Assessment (Meta-Analysis). American Journal of Psychiatry, 161, 2295-2302. https://doi.org/10.1176/appi.ajp.161.12.2295

[26] Aasland, O.G., Hem, E., Haldorsen, T. and Ekeberg, O. (2011) Mortality among Norwegian Doctors 1960-2000. BMC Public Health, 11, 173. https://doi.org/10.1186/1471-2458-11-173

[27] Jiao, Y., et al. (2014) Cross-Sectional Study of Attitudes about Suicide among Psychiatrists in Shanghai. BMC Psychiatry, 14, 87. https://doi.org/10.1186/1471-244X-14-87

[28] Siu, C., Yuen, S.K. and Cheung, A. (2012) Burnout among Public Doctors in Hong Kong: Cross-Sectional Survey. Hong Kong Medical Journal, 18, 186-192.

[29] Pan, Y.J., Lee, M.B. and Lin, C.S. (2009) Physician Suicide in Taiwan, 2000-2008: Preliminary Findings. Journal of the Formosan Medical Association, 108, 328-332. https://doi.org/10.1016/S0929-6646(09)60073-5

[30] Juel, K., Mosbech, J. and Hansen, E.S. (1999) Mortality and Causes of Death among Danish Medical Doctors 1973-1992. International Journal of Epidemiology, 28, 
456-460. https://doi.org/10.1093/ije/28.3.456

[31] Hawton, K. (2001) Suicide in Doctors: A Study of Risk according to Gender, Seniority and Specialty in Medical Practitioners in England and Wales, 1979-1995. Journal of Epidemiology and Community Health, 55, 296-300. https://doi.org/10.1136/jech.55.5.296

[32] Petersen, M.R. and Burnett, C.A. (2008) The Suicide Mortality of Working Physicians and Dentists. Occupational Medicine, 58, 25-29. https://doi.org/10.1093/occmed/kqm117

[33] Carpenter, L.M., Swerdlow, A.J. and Fear, N.T. (1997) Mortality of Doctors in Different Specialties: Findings from a Cohort of 20000 NHS Hospital Consultants. Occupational and Environmental Medicine, 54, 388-395. https://doi.org/10.1136/oem.54.6.388

[34] Dyrbye, L.N., et al. (2014) Burnout among US Medical Students, Residents, and Early Career Physicians Relative to the General US Population. Academic Medicine, 89, 443-451. https://doi.org/10.1097/ACM.0000000000000134

[35] Fridner, A., Belkić, K., Marini, M., Sendén, M.G. and Schenck-Gustafsson, K. (2012) Why Don't Academic Physicians Seek Needed Professional Help for Psychological Distress? Swiss Medical Weekly, 142, 1-8. https://doi.org/10.4414/smw.2012.13626

[36] Aasland, O.G., Rosta, J. and Nylenna, M. (2010) Healthcare Reforms and Job Satisfaction among Doctors in Norway. Scandinavian Journal of Public Health, 38, 253-258. https://doi.org/10.1177/1403494810364559

[37] Duarte, Z. and Farias, L. (2009) A Medicina na Era da Informação. EDUFBA, Salvador.

[38] Oliveira, M. (2011) Ciência da Informação e Biblioteconomia: Novos conteúdos e espaço de atuação. UFMG, Belo Horizonte.

[39] Higgins, J.P.T. and Greens, S. (2011) Cochrane Handboook for Systematic Review of Interventions. Version 5.1.0, the Cochrane Collaboration.

[40] Moher, D., Liberati, A., Tetzlaff, J. and Altman, D.G. (2009) Preferred Reporting Items for Systematic Reviews and Meta-Analyses: The PRISMA Statement. PLoS Medicine, 6, e1000097. https://doi.org/10.1371/journal.pmed.1000097

\section{Submit or recommend next manuscript to SCIRP and we will provide best service for you:}

Accepting pre-submission inquiries through Email, Facebook, LinkedIn, Twitter, etc. A wide selection of journals (inclusive of 9 subjects, more than 200 journals) Providing 24-hour high-quality service User-friendly online submission system Fair and swift peer-review system Efficient typesetting and proofreading procedure Display of the result of downloads and visits, as well as the number of cited articles Maximum dissemination of your research work

Submit your manuscript at: http://papersubmission.scirp.org/ Or contact health@scirp.org 